Baldwin says: "I have never seen a parallel case," while Ochsner writes: "I have had similar cases, in which there existed a rudimentary formation of the uterus, tubes or vagina and in which these organs were represented by fascia-like formations, but I have never scen a casc in which the uterus was entirely absent."

628 Elm Street.

\section{COMPLETE INVERSION OF THE UTERUS WITH PROLAPSE.}

\section{A. C. OLMSTED, M.D.}

WELLS, NEV.

The comparative infrequency of the condition and some unusual surroundings prompt the report of this case.

Patient.-L., Shoshone squaw, aged 29. This was the sixth pregnancy and was normal so far as I was able to learn. She is half-civilized and lives in a frame house, but adheres to the custom of seeking solitude out of doors at the time of labor.

History.-I was called Sept. 20, 1906, and was told at the time that the child had been born two hours, but the placenta had not yet come away. I reached the patient four and onehalf hours after delivery, finding her in the sagebrush, near a mountain stream, lying on the ground with only a blanket for covering.

Vxamination.-1 found her suffering from shock and halfconscious; pulse was 135 , but the extremities were warm. Her husband said that she had complained of but little pain. I found the placenta lying on the ground between the thighs, completely detached and with membranes entire. Saturation of clothing and soil gave evidence of a profuse hemorrhage. A tumor, larger than a large orange, projected from the vulva. Bimanual examination showed this to be the inverted and prolapsed uterus, the entire body of the organ being outside the vagina.

Treatment and Result.-After cleansing as well as was possible under the circumstances, the fundus was pushed upward until it passed the relaxed cervical ring. The fingers in the uterus then held the fundus well up until a contraction occurred.

Improvement was rapid, and an hour later the patient said she was "all right." I did not see her again for three weeks, but received daily reports of her rapid and steady recovery. On Oct. 12. 1906, she came to my office for examination. The uterus was found to be of normal size for corresponding period of puerperium; there was no indentation of fundus, no tenderness, no prolapse. The patient denied having pulled on the cord, and said that she was in a recumbent position at the time of delivery. The husband said, however, that she had pulled on the tumor, but soon desisted on account of pain.

\section{A RARE FORM OF MALIGNANT TUMOR OF THE TESTICLE. \\ WII.LIAM A. ROIFE, M.D. BOSTON.}

The following case is reported as being of interest, more especially from a pathologic viewpoint:

History.-C. D. R., aged 38, married, of good previous history, noticed in August, 1906, a commencing enlargement of the left testicle. This was thought to be due to a slight injury received while riding a bicycle. The man was first seen in October, at which time he was in good physical condition except for the enlarged testicle, which was moderately painful, and caused considerable discomfort from the dragging sensation along the cord. The patient's paternal grandfather died from cancer of the liver, but otherwise the family history was unimportant.

Examination.-The testicle was found to be uniformly en. larged, measuring about $8 \mathrm{~cm}$. in length by $6 \mathrm{~cm}$. in diameter.
The epididymis could not be clearly made out, and there was an absence of fluid in the scrotal sac. Pressure on the testicle caused much pain. Operation was advised at this time but declined, and the patient left for his home in a distant eity. I did not see the patient again until December 3 , at which time the testicle was much larger and there was a history of a loss of 25 pounds in weight. At this examination my attention was directed to a small node situated in the skin over the right costal margin in a line with the right nipple. This was hard and painful on pressure, and appeared to be a metastatic growth, but operation on the testicle was advised for the relief of pain and increasing discomfort.

Operation.-Castration was done and the postoperative history was uneventful.

"Macroseopic Examination.-On section the testicle presented a dark red appearance, was firm in consistency and suggested a melanotic sarcoma. The tumor, together with the skin node, was sent to the pathologic laboratory of the Boston City Hospital, and the following is the report of the pathologist, Dr. Samuel T. Orton: "Specimen consists of a tumor, a flat sheet of tissue, and several fragments preserved in alcohol; it is oroid, about $9 \mathrm{~cm}$. in length by $6 \mathrm{~cm}$. across. At one end are the remains of the caput epididymis. On section it is dark red in color with a few small grayish areas at various points especially near its periphery. The flat (tunic) membranous sheet varies in thickness in various areas; one of the smaller pieces is an elliptical piece of skin about $2 \mathrm{~cm}$. in diameter with a firm nodular mass at its center.

"Microscopic Examination.-The tumor is largely disintegrated and hemorrhagic. The few intact areas consist of groups of polyhedral cells more or less surrounded by a layer of flat. deeply staining (syncytial) cells, some of which are multimuleated. The tumor in the skin is of the same structure. Tumic shows chronic inflammatory change, but no tumor masses.

"Diagnosis.-Chorion-epithelioma. Chorion-epithelioma in this site places the tumor among the teratomata."

Subsequent Mistory.-The patient died December 25 from metastatic involvement of the lungs.

The attending physician, Dr. W. T. Crosby, Manchester, N. H., used the trypsin treatment for cancer, but with no apparent benefit.

A tumor of this nature is rare in the testicle, and I have been unable to find any reference to a similar case. 755 Boylston Street.

\section{SCURVY IN AN ADULT.}

\section{A. F. MAISCH, M.D. GLOBE, ARIZ.}

l'atient.-Male, American, aged 33, robust; height 5 feet 9 inches; weighed 173 pounds; complained of bleeding from the mouth and pain while chewing food. Condition had existed two weeks.

History--Negative family history; no hemophilia; no serious illness; denies lues.

Examination.-No apparent anemia or enlargement of lymphatics; muscles were solid, no tenderness on pressure. Theart, Jungs and kidneys normal. Mouth showed slight oozing of blood at the margin of the gums; no pus; bleeding free cn slight pressure and also hemorrhage from numerous areas on hard palate. On further questioning, patient said he had been employed building roads on an Indian reservation for the past five months. His food during this time had been limited to such articles as beans, coffee, salt pork and potatoes; once a week had fresh meat, but no fruits or vegetables, except potatces.

Diagnosis.--Scurvy.

Treatment Local.-Saturated solutions of potassium per: manganate as mouth wash; an 8 per cent. solution silver nitrate to gums, also hydrogen peroxid to check bleeding Constitutional: Jemons, oranges, fresh meat and vegetables.

Result.-Pain-became less after I2 hours; bleeding ceased in 48 hours. Two weeks later the patient was entirely well. 